\title{
Functional Analysis of Expressed Sequence Tags from Hanwoo (Korean Cattle) cDNA Libraries
}

Dajeong Lim*, Mi-jeong Byun*, Yong-Min Cho*, Duhak Yoon*, Seung-Hwan Lee*, Younhee Shin** and Seok-ki Im* National Institute of Animal Science, RDA, 330-801, Rep. of Korea*, Insilicogen, Inc., Suwon Chomdan Venture Valley, 958, Gosoek-dong, Gwonseon-gu, Suwon-si, Gyeonggi-do, 441-813, Korea**

\author{
한우 cDNA 라이브러리에서 발현된 ESTs의 기능분석 \\ 임다정*· 변미정* · 조용민*·윤두학* · 이승환* · 신윤희** · 임석기* \\ 농촌진흥청 축산과학원 생명환경부*, 인실리코젠**
}

\begin{abstract}
적 요
본 연구는 한우의 지방, 간, 등심조직에서 유전자 염기서열을 확보하여 생산된 57,598 개의 유전자 발현단편 데이 터의 기능규명을 실시하였다. 유전자 발현단편 서열은 Assembly 과정을 통하여 unique한 서열인 4,759 contigs와 7,587 singletons을 확보하였으며, 얻어진 전사체를 이용하여 NCBI의 non-redundant 단백질 데이터베이스에 대하여 서 열유사성 검색 (BLAST)을 하여 유전자의 기능을 예측할 수 있었다. 또한 기능에 대한 모호성을 확실히 하기 위해 Gene Ontology 용어를 사용하여 한우의 세 조직에서 확보된 서열들의 생물학적 특성을 기술하였다. Gene Ontology 는 모든 기능이 계층적으로 표현되어 있기 때문에, 각 계층에 대하여 유의적인 기능 여부를 확인하기 위하여 통계 분석인 Pearson's chi-square test를 실시하여 통계적으로 유의한 기능들을 산출할 수 있었다. 그 결과, Molecular function, Biological process, Cellular component 각각의 $\mathrm{GO}$ category에서 $13,16,8$ 개의 유의적인 $\mathrm{GO}$ terms이 검출되었 다. 또한, 한우의 세 조직에 대하여 조직특이적 유전자의 존재여부를 판단하기 위하여 Audic's test를 실시하여 세 조직에서 각각 조직특이적으로 발현되는 유전자들을 검출할 수 있었다. 이러한 생물정보학적 방법들을 사용하여 한 우의 세 조직에서 발현된 대량의 서열들에 대한 기능을 예측할 수 있었으며, 통계 검증을 통하여 유의적으로 검출 된 유전자들은 추후에 실험적 검증을 실시하여 충분한 정보를 확보할 수 있을 것으로 사료된다.
\end{abstract}

(Key words : Hanwoo, EST, Gene Ontology, Audic's test)

\section{I . INTRODUCTION}

The bovine genome project has been started at the Baylor College of Medicine Human Genome Sequencing Center and the Genome British Columbia Sequencing and Mapping Platform at the British Columbia Cancer Agency (BCCA) in December 2003. The first assembly is based on 3.3-fold coverage of the bovine genome and by 2005 . Now, the final draft assembly (7.1 fold coverage) is available. The cow is also the first ruminant mammal to have its genome sequenced. There is the reference point used to identify domestication animals that are better suited to a particular market or environment using genomics studies. Successful beef production requires efficient growth rate, meat quality and high levels of reproductive success to be accurately controlled by the development of strategy for functional gene discovery for meat traits using quantitative trait
loci(QTL) mapping. A meat quality of cattle is determined by intramuscular fat deposition (marbling) (Lee et al., 2007) and might be improved by functional genomics studies in genetic factors. Beef is graded according to the amount of marbling since marbling makes beef more tender, flavorful, and juicy. It is one of the main factors used to determine beef quality grade in the United States (USDA, 1989), Japan (JMGA, 1988), and Korea (Lee et al., 2007). Hanwoo is indigenous cattle in Korea and has been maintained as a beef cattle breed.

There have been functional genomics studies in the cattle using molecular and bioinformatics analysis (Sonstegard and van Tassell, 2004). There is often incomplete genomic sequence of agriculturally important animals. Thus, full-length enriched cDNA is valuable resources based on transcriptome for functional genomics. Analysis and Functional annotation of an EST

Corresponding author : Yong-Min Cho, Division of Animal Genomics and Bioinformatics National Institute of Animal Science, RDA, 330-801, Rep. of Korea

Tel: +82-31-290-1607, Fax:+82-31-290-1602, E-mail: variancei@rda.go.kr 
collection is one of the most effective and popular method for expressed genes. However, the study of bovine ESTs has been quite limited. A muscle specific expression data from EST library analysis from cattle was used to predict sets of genes whose expression was enriched in muscle and cardiac tissues (Zadissa et al., 2007). ESTs from the 5' end are efficient method for protein coding information and functional implication of cDNA. For example, it was attempted to characterize a normalized cDNA library from four distinct intestinal locations (duodenal, jejunal and ileal small intestine, colon) of Holstein dairy cattle (Baumann et al., 2005). A cDNA library is a pool of cDNA clones that represent the profile of mRNA expression for particular tissues or cells. cDNA libraries are very beneficial to the gene discovery and protein. It is also applied through normalization and subtraction techniques to study differential gene expression pattern. Comparative analysis of bovine ESTs with sequence data from other species provides information for comparative map development. Furthermore, the unique sequences from ESTs were spotted onto a microarray for gene expression profiling (Dvorak et al., 2005).

Therefore, this study was conducted to investigate a large-scale EST analysis from 3 cDNA libraries: intermuscular fat, longissimus dorsi and liver and analyzed their functional characteristics, functional annotation of transcripts, Gene Ontology (GO), and tissue-specific gene expression analysis.

\section{П. METHODS AND MATERIALS}

\section{1. cDNA library construction and cDNA sequencing}

Liver, intermuscular fat and longissimus dorsi tissues were generated from Hanwoo(Korean cattle) steer immediately after slaughter at 24 month of age $(n=4)$ and immediately frozen in liquid nitrogen and store at $-80^{\circ} \mathrm{C}$. Total RNAs were extracted from liver, intermuscular fat and longissimus dorsi tissues using the TRIzol reagent (Gibco BRL Life Technologies Ltd.), that was the same methods previously reported (Lee et al., 2006). RNA intensity was confirmed by examining the $28 \mathrm{~S}$ and $18 \mathrm{~S}$ ribosomal RNA bands on ethidium bromide stained $1.5 \%$ agarose gel. Total RNA extracted from four different Hanwoo steers were pooled and enriched for mRNA using the oligotex mRNA midi kit (Qiagen Ltd.). The cDNA library was constructed using $\lambda$ ZAP $^{\circledR}$ cDNA synthesis/Gigapack III gold cloning kit (Stratagene). The cDNA was prepared using $5 \mu \mathrm{g}$ of
mRNA and oligo(dT)18 primer, size-fractionated and inserted into the Uni-ZAP XR vector using Xho I linker-primer and EcoR I adaptor. The library was stored at 4 and $-80^{\circ} \mathrm{C}$ in $7 \%$ DMSO for long-term storage. Plasmid DNAs were purified by core-one plasmid HTS prep kit (CoreBiosystems). Single-pass sequencing of the 5'-termini of cDNA clones was performed using the $\mathrm{ABI}$ 3730XL (PE Applied Biosystems) and the ABI prism Big Dye Terminator Ver 3.1 (PE Applied Biosystems). The Bovine EST trace data were base-called using Phred (Ewing and Green, 1998) and were vector-clipped by a cross-match program (Gordon et al., 1998) with vector sequences. Vector-screened EST sequences were filtered according to repetitive sequence and low-complexity regions using RepeatMasker (http://ftp.genome.washington. edu/RM/RepeatMasker.html). The ESTs were clustered and assembled using CAP3 program (Huang and Madan, 1999). We filtered out transcripts of less than $200 \mathrm{bp}$ from our dataset using SeqClean. The registered accession numbers from the NCBI dbEST database are GH296597-GH332022.

\section{Gene Ontology annotation and functional analysis}

To annotate bovine ESTs with Gene Ontolgy, they were executed with a sequence similarity search against the tentative consensus (TC) sequences of the Bos taurus Gene Index (BtGI release 12.0) using BLASTN (Altschul et al., 1997) with cutoff values being 95\% identity, $60 \%$ coverage, and an e-value $<0.00001$ for GO identification. Then, GO categorization on the ESTs were done with the GO profile of the Gene Ontology Consortium (http://www.geneontology.org). If EST sequences do not satisfy the above conditions, it is placed in the putative novel transcript group. For GO annotation of these novel transcripts, we performed a BLASTX search against the nonredundant protein sequence database downloaded from $\mathrm{ftp} / / / \mathrm{ftp} . n c b i . n i h . g o v /$ blast/db/.

From each identified ontology term, a list of ESTs, which share functional annotation, were retrieved. To test if function bias exists in the ESTs in this study, Pearson's chi-square test was used to determine statistical significance. As described previously (Zhong et al., 2004), mapping gene $G$ in go $(G)=0$ or 1 in a particular GO term was compared with the gene list that the null hypothesis of no association between them with cording them into equal distribution of binary random variables. The significance tests were performed for the $2^{\text {nd }}$ level of GO terms to leaf terms with applying a Bonferroni correction (Bonferroni, 1936) to correct the 
multiple test problems. We used the hierarchical classification of GO terms that the first level consists of Molecular Function, Biological process and Cellular component terms. We used 0.05 significance level to reject the null hypothesis and identified only the significant leaf nodes with the algorithm described elsewhere (Kim et al. 2007). Briefly, the algorithm searches all child nodes to identify if any of its child nodes show significance.

\section{Statistical Analysis of tissue specific gene expression}

We performed gene expression profiling of our sequence data using Audic's test (Audic and Claverie, 1997). Significance test of gene expression profiles between a pair of the cDNA libraries was performed using Audic's test. As described by Noh et al. (Noh et al., 2006), the total number of assembled ESTs from all transcripts is $N$, the number of ESTs from a specific tissue is $N_{2}$, the number of ESTs from all other tissues is $N_{l}$, the number of ESTs assembled on a given gene is $\mathrm{y}$, and the number of ESTs from all other tissues in a given gene is $\mathrm{x}$. Thus, $N_{1}+N_{2}=N$ and $x+y=n$. In hypothesis test, the null hypothesis is that there is no difference between the ratio of the number of ESTs from a specific tissue and the number of ESTs assembled on a given gene $\left(y / N_{2}\right)$ and the ratio of the number of ESTs from all other tissues in a given gene and the number of ESTs from all other tissues $\left(x / N_{l}\right)$. We evaluated significance of the difference between the ratios. Given that $\mathrm{x}$ was derived from N1, the conditional probability that y would be derived from $\mathrm{N} 2$ is

$$
p(y x)=\left(\frac{N_{2}}{N_{1}}\right)^{y} \frac{(x+y) !}{x ! y !\left(1+\frac{N_{2}}{N_{1}}\right)^{(x+y+1)}}
$$

The $P$-value was calculated according to the formula

$$
\text { Pvalue }=\sum_{y}^{n} p(y x)=\sum_{y}^{n}\left(\frac{N_{2}}{N_{1}}\right)^{y} \frac{(x+y) !}{x ! y !\left(1+\frac{N_{2}}{N_{1}}\right)^{(x+y+1)}}
$$

We used the 0.01 significance level to reject the null hypothesis. We defined the genes as tissue-specific genes if they accept the alternative hypothesis, i.e. the ratio of ESTs in that tissue for a given gene is significantly different than the ratio of ESTs in all other tissues. Since there was a multiple test problem, FDR (False Discovery Rate) correction was applied for the test. Results of multiple tests can make unexpected number of type I error. Bovine contigs in all libraries were subjected to the following criteria: contigs should consist of a minimum number of 5 ESTs and those enrichment values should be greater than 2 .

\section{RESULTS AND DISCUSSION}

\section{Generation of ESTs data}

To avoid inherent problems in the computational processing of EST sequences that is the data redundancy and quality, we used a reliable strategy of processing ESTs (Fig. 1). After sequence assembling, a set of unique sequences has been obtained. Of these, 4,759 contigs include two or more ESTs, while other 7,587 represent singleton from 57,598 ESTs. Table 1 shows library information of cDNA clones about each tissue. Average number of ESTs per contig was about 10 for 3 libraries.

To facilitate comparative annotation of total 12,346 transcripts, for which cDNA sequences are sparingly available in porcine, these sequences were aligned by using BLASTX program against the non-redundant protein database. We applied the strict threshold for definition of homologous sequence because of it not

\begin{tabular}{|c|c|}
\hline EST Sequencing \& assembly & Functional annotation using Gene Ontology \\
\hline $\begin{array}{c}\text { 5' single-pass sequencing of 57,598 cDNA } \\
\text { inserts using Phred } \\
\text { Vector clippin using cross_match } \\
\text { Trimming transcript (less than } 200 \mathrm{bp} \text { ) using SeqClean } \\
\text { EST assembly using CAP3 } \\
4,759 \text { contigs and } 7,857 \text { singletons }\end{array}$ & $\begin{array}{l}4,759 \text { contigs \& } 7,587 \text { singlletons } \\
\text { BLASTN against TIGR BtGI TC sequences } \\
\text { (e-value : } 10-5 \text {, coverage : } 60 \% \text {, identity : } 96 \% \text { ) } \\
\text { Gene ontology annotation using GO files } \\
\text { significance test of GO terms from the } 2^{\text {nd }} \text { level } \\
\text { to all leaf nodes using Pearson's chi-square test }\end{array}$ \\
\hline
\end{tabular}

Fig. 1. The overall strategy for processing of ESTs 
Table 1. Library information of cDNA clones

\begin{tabular}{ccccc}
\hline \multicolumn{1}{c}{ Library } & Fat & Loin & Liver & Total \\
\hline \hline No. of ESTs (Before Assembly) & 18,930 & 18,883 & 20,145 & 57,598 \\
No. of ESTs (After Assembly) & 17,926 & 17,924 & 19,363 & 55,213 \\
\hline
\end{tabular}

being a cross-species sequences comparison that removes blast hits with paralogous sequences. Transcripts enriched for these libraries are shown in Table 2. The most abundant transcript is cytochrome oxidase subunit III in fat and loin and albumin in liver. The second abundant transcripts were MSTP008, Chain A, Bovine Heart Cytochrome $\mathrm{C}$ Oxidase at the fully Oxidized state and FGG protein, respectively.

\section{Gene Ontology annotation and functional analysis}

To classify transcripts by putative function, enrichment bias in the GO categories is manifested both in the number of transcript in this study and in the TIGR BtGI. In Fig. 2, the result is displayed as three separate graphs, each representing the $2^{\text {nd }}$ level of GO terms according to the GO consortium. We further have conducted to find unique function by using significance test of GO terms from the 2nd level to all leaf nodes (Table 3). We found that 13, 26 and 8 significant leaf nodes are unique in the transcripts according to $3 \mathrm{GO}$ categories, molecular function, biological process and cellular component. In farm animals, dietary carbohydrates are so important source of energy for maintenance, growth and production (Nafikov and Beitz, 2007). Glucose is also a primary energy source for certain animal tissues and a precursor for lactose synthesis in the mammary gland. Thus, understanding
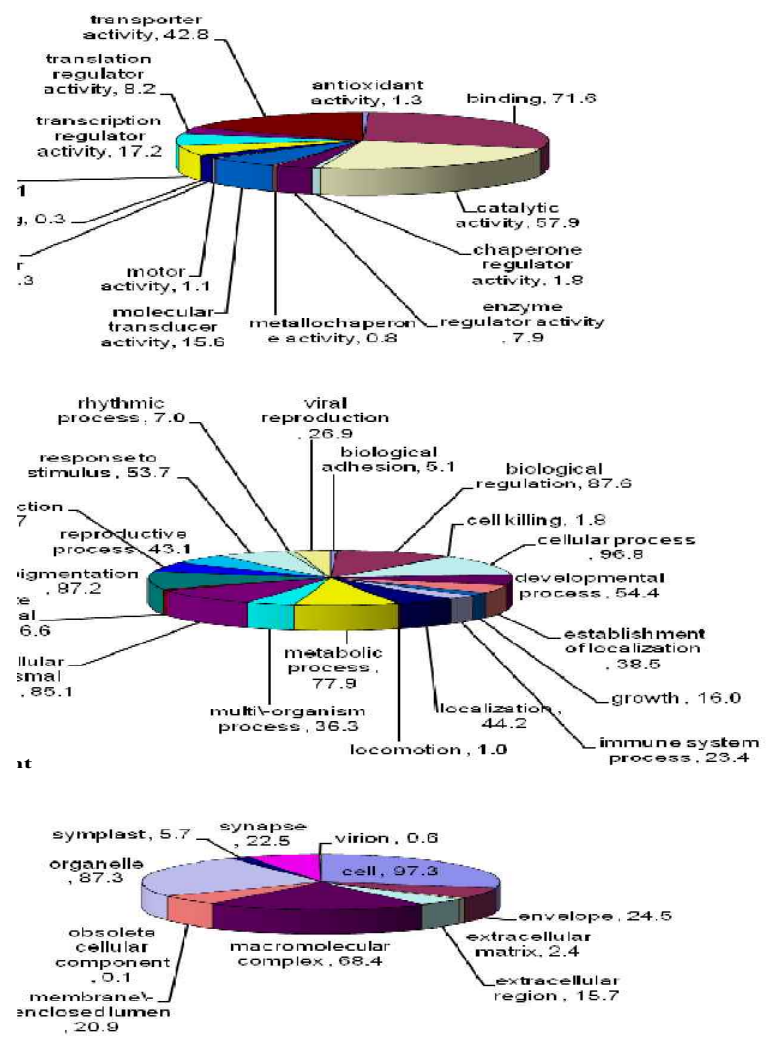

Fig. 2. Gene Ontology distribution of Hanwoo transcripts. (A), (B) and (C) indicate molecular function, biological process and cellular component, respectively.

Table 2. BLAST results of contigs composed of the 10 most redundant ESTs from 3 libraries (against the $\mathrm{nr}$ protein database)

\begin{tabular}{lllllc}
\hline \multicolumn{1}{c}{ Contig ID } & $\begin{array}{l}\text { No. of } \\
\text { ESTs }\end{array}$ & Accession ID & BLAST hit & score e-value \\
\hline \hline Bovine_contig01705 & 2213 & AAM08332.1 & cytochrome oxidase subunit III [Bos taurus] & 451 & e-125 \\
\hline Bovine_contig02938 & 1887 & NP_851335.1 & albumin [Bos taurus] & 1219 & 0 \\
\hline Bovine_contig04107 & 1002 & IV54 & $\begin{array}{l}\text { A Chain A, Bovine Heart Cytochrome C Oxidase At } \\
\text { The Fully Oxidized State }\end{array}$ & 831 & 0 \\
\hline Bovine_contig01942 & 672 & AAI02630.1 & FGG protein [Bos taurus] & 858 & 0 \\
\hline Bovine_contig02217 & 633 & ABV70449.1 & NADH dehydrogenase subunit 5 [Bos taurus] & 923 & 0 \\
\hline Bovine_contig03306 & 518 & NP_001029206.1 & glyceraldehyde-3-phosphate dehydrogenase [Bos taurus] & 671 & 0 \\
\hline Bovine_contig03068 & 507 & XP_587666.3 & $\begin{array}{l}\text { PREDICTED : similar to Fibrinogen beta chain } \\
\text { cursor [Bos taurus] }\end{array}$ & 991 & 0 \\
\hline Bovine_contig04133 & 498 & AAQ13510.1 & AF109362_1 MSTP008 [Homo sapiens] & 95 & $2 \mathrm{e}-17$ \\
\hline Bovine_contig03886 & 479 & AAX37027.1 & actin alpha 1 [synthetic construct] & 765 & 0 \\
\hline Bovine_contig02803 & 391 & NP_001030265.1 & integral membrane protein 2B [Bos taurus] & 547 & E-154 \\
\hline
\end{tabular}


Table 3. List of the Gene Ontology significant leaf terms enriched in Hanwoo (Korean Native Cattle) transcripts

(a) Molecular Function

\begin{tabular}{lll}
\hline \multicolumn{1}{c}{ GO term } & \multicolumn{1}{c}{ Description } & P-value \\
\hline \hline GO:0003796 & lysozyme activity & $1.86 \mathrm{E}-10$ \\
GO:0003723 & RNA binding & $2.21 \mathrm{E}-06$ \\
GO:0016251 & general RNA polymerase II transcription factor activity & $2.30 \mathrm{E}-06$ \\
GO:0051287 & NAD binding & $1.42 \mathrm{E}-05$ \\
GO:0004030 & aldehyde dehydrogenase [NAD(P)+] activity & $4.73 \mathrm{E}-05$ \\
GO:0004889 & nicotinic acetylcholine-activated cation-selective channel activity & $4.73 \mathrm{E}-05$ \\
GO:0004693 & cyclin-dependent protein kinase activity & $2.20 \mathrm{E}-16$ \\
GO:0004702 & receptor signaling protein serine/threonine kinase activity & $1.12 \mathrm{E}-08$ \\
GO:0001601 & peptide YY receptor activity & $6.33 \mathrm{E}-12$ \\
GO:0030544 & Hsp70 protein binding & $2.20 \mathrm{E}-16$ \\
GO:0004540 & ribonuclease activity & $1.01 \mathrm{E}-09$ \\
GO:0030332 & cyclin binding & $2.20 \mathrm{E}-16$ \\
GO:0004365 & glyceraldehyde-3-phosphate dehydrogenase (phosphorylating) activity & $1.99 \mathrm{E}-06$ \\
\hline
\end{tabular}

\section{(b) Biological Process}

\begin{tabular}{lll}
\hline GO term & \multicolumn{1}{c}{ Description } & P-value \\
\hline \hline GO:0007095 & mitotic G2 checkpoint & $2.20 \mathrm{E}-16$ \\
GO:0007141 & male meiosis I & $2.20 \mathrm{E}-16$ \\
GO:0016251 & general RNA polymerase II transcription factor activity & $2.30 \mathrm{E}-06$ \\
GO:0019835 & cytolysis & $2.01 \mathrm{E}-08$ \\
GO:0009555 & male gametophyte development & $2.20 \mathrm{E}-16$ \\
GO:0000090 & mitotic anaphase & $2.20 \mathrm{E}-16$ \\
GO:0042742 & defense response to bacteria & $5.53 \mathrm{E}-06$ \\
GO:0042023 & DNA endoreduplication & $1.63 \mathrm{E}-15$ \\
GO:0007283 & spermatogenesis & $1.67 \mathrm{E}-05$ \\
GO:0006941 & striated muscle contraction & $7.09 \mathrm{E}-06$ \\
GO:0000083 & G1/S-specific transcription in mitotic cell cycle & $2.20 \mathrm{E}-16$ \\
GO:0045034 & neuroblast division & $2.20 \mathrm{E}-16$ \\
GO:0009451 & RNA modification & $1.09 \mathrm{E}-09$ \\
GO:0008315 & meiotic G2/MI transition & $2.20 \mathrm{E}-16$ \\
GO:0016245 & hyperphosphorylation of RNA polymerase II & $2.20 \mathrm{E}-16$ \\
GO:0006006 & glucose metabolism & $1.39 \mathrm{E}-05$ \\
GO:0007089 & traversing start control point of mitotic cell cycle & $2.20 \mathrm{E}-16$ \\
GO:0016998 & cell wall catabolism & $1.27 \mathrm{E}-10$ \\
GO:0009992 & cellular osmoregulation & $6.15 \mathrm{E}-06$ \\
GO:0000910 & cytokinesis & $3.99 \mathrm{E}-09$ \\
GO:0042542 & response to hydrogen peroxide & $6.90 \mathrm{E}-07$ \\
GO:0000076 & DNA replication checkpoint & $2.20 \mathrm{E}-16$ \\
GO:0000084 & S phase of mitotic cell cycle & $1.83 \mathrm{E}-13$ \\
GO:0000089 & mitotic metaphase & $2.20 \mathrm{E}-16$ \\
GO:0006412 & protein biosynthesis & $1.52 \mathrm{E}-05$ \\
GO:0000086 & G2/M transition of mitotic cell cycle & $2.20 \mathrm{E}-16$ \\
GO:0008284 & positive regulation of cell proliferation & $7.07 \mathrm{E}-11$ \\
\hline
\end{tabular}




\begin{tabular}{llc}
\hline \multicolumn{1}{c}{ GO term } & \multicolumn{1}{c}{ GO Description } & P-value \\
\hline \hline GO:0005770 & late endosome & $1.01 \mathrm{E}-05$ \\
GO:0005625 & soluble fraction & $7.15 \mathrm{E}-05$ \\
GO:0010005 & cortical microtubule (sensu Viridiplantae) & $2.20 \mathrm{E}-16$ \\
GO:0005839 & proteasome core complex (sensu Eukaryota) & $3.72 \mathrm{E}-05$ \\
GO:0009277 & cell wall (sensu Fungi) & $7.32 \mathrm{E}-06$ \\
GO:0000307 & cyclin-dependent protein kinase holoenzyme complex & $2.20 \mathrm{E}-16$ \\
GO:0030014 & CCR4-NOT complex & $6.97 \mathrm{E}-11$ \\
GO:0009574 & preprophase band & $2.20 \mathrm{E}-16$ \\
\hline
\end{tabular}

dietary glucose availability is important to manipulate of the production and quality of agricultural foods. Hanson and Ballard (1967) reported that glucose and acetate are the main carbon sources for fatty acid synthesis in porcine and ruminant adipose tissue (Hanson and Ballard, 1967). About $68 \%$ of total ESTs were generated from fat and liver. Thus, those ESTs related to glucose metabolism or lipid synthesis may be a valuable target for further study. Through these results, we are able to obtain candidate genes for quantitative traits whereas previous studies were obtained from experiments for identification of QTLs. While the comparison of the Pearson chi-square test of particular GO terms is based on non-redundant data sets, digital gene expression profiling is based upon quantitative differences between two different datasets. Functional characterization of the unidentified genes might be lead to important findings with regard to the processes at work in these tissues (Hansen et al., 2004).

\section{Statistical Analysis of tissue specific gene expres- sion}

We also performed statistical analysis for identifying tissue-specific genes based on EST tissue information. Bovine expression data, based on EST sequences were analyzed for tissue-specific expression using Audic's test (Audic and Claverie, 1997). The contigs were selected those contigs containing five or more ESTs and 1,649 contigs were retained. There were 325, 210 and 238 genes expressed significantly higher number of transcripts in fat, loin and liver data sets, respectively. Table 4 shows list of tissue-specific unique genes that have the best 10 significance level. Of loin muscle-highly expressed genes, carbonic anhydrase III (muscle specific) was located in Bos taurus chromosome 14. Of researches about carbonic anhydrase III, Vaananen et al reported that muscle-specific carbonic anhydrase III is a sensitive marker of muscle damage in human with neuromuscular diseases (Vaananen et al., 1988). Carbonic anhydrase has a role in ion transport, provision of bicarbonate for fatty acid synthesis, gluconeogenesis, ureagenesis (Coulson and Herbert, 1984). Tenderness is usually thought of as being based on background tenderness, collagen content and extent of crosslinking (Sifre et al., 2005), and myofibrillar degradation. Some studies have suggested that sarcomere length might be contribute to tenderness, particularly in cold shortening due to increased overlap of thick and thin filaments. Carbonic anhydrase III may be a marker directly associated with beef carcass tenderness, which could potentially lead to the development of an immunochemical assay. For example, in fat-highly expressed genes, collagen and collagen, type III, alpha 1 were more highly expressed in the transcripts. The amount of collagen in muscle or fat has been use as a measure of muscle desirability or tenderness and fat thickness. This would indicate that, as expected, tissue-specific genes were related with functions of those tissues. Tissue-specific cDNA library sequences (i.e. expressed sequence tags) yield a detailed snapshot of gene expression and are useful in developing secondgeneration molecular resources (i.e., microarrays) for gene expression profiling (Baumann et al., 2005). This approach also employs gene expression information from the bovine genome.

In this study, we could identify the transcripts expressed in 3 libraries. In the near future, we can experimentally verify transcripts that would be of general interest to integrate with the bovine genome sequences. These data will also contribute in efforts to annotate the bovine genome. 
Table 4. Digital gene expression profiling using Audic's test

\begin{tabular}{|c|c|c|c|c|}
\hline Tissue & Local ID & Gene description (nr blast hit) & P-value & Adjusted P-value \\
\hline \multirow{10}{*}{ Fat } & Contig3975 & caveolin 1 & 0 & $3.03214 \mathrm{E}-05$ \\
\hline & Contig4644 & $\begin{array}{l}\text { Complex Of Gs Alpha With The Catalytic Domains Of } \\
\text { Mammalian Adenylyl Cyclas }\end{array}$ & 0 & $6.06428 \mathrm{E}-05$ \\
\hline & Contig1319 & collagen, type III, alpha 1 & $1.11 \mathrm{E}-16$ & $9.09642 \mathrm{E}-05$ \\
\hline & Contig2692 & THRSP protein & $1.11 \mathrm{E}-16$ & 0.000121286 \\
\hline & Contig3501 & ADIPO_BOVIN Adiponectin precursor & $1.11 \mathrm{E}-16$ & 0.000151607 \\
\hline & Contig397 & microfibrillar associated protein 5 & $1.11 \mathrm{E}-16$ & 0.000181928 \\
\hline & Contig4133 & AF109362_1 MSTP008 & $1.11 \mathrm{E}-16$ & 0.00021225 \\
\hline & Contig479 & collagen, type I, alpha 2 & $1.11 \mathrm{E}-16$ & 0.000242571 \\
\hline & Contig608 & paraoxonase 2 & $1.11 \mathrm{E}-16$ & 0.000272893 \\
\hline & Contig144 & fatty acid binding protein 5 & 4.44E-16 & 0.000303214 \\
\hline \multirow{10}{*}{$\begin{array}{l}\text { Loin } \\
\text { muscle }\end{array}$} & Contig1760 & HSPB1_BOVIN Heat shock protein beta $1(\mathrm{HspB} 1)$ & 0 & $3.03214 \mathrm{E}-05$ \\
\hline & Contig3246 & carbonic anhydrase III, muscle specific & 0 & $6.06428 \mathrm{E}-05$ \\
\hline & Contig3262 & troponin $\mathrm{T} 1$, skeletal, slow & 0 & $9.09642 \mathrm{E}-05$ \\
\hline & Contig3306 & glyceraldehyde-3-phosphate dehydrogenase & 0 & 0.000121286 \\
\hline & Contig3475 & PREDICTED: similar to myosin heavy chain $2 \mathrm{a}$ & 0 & 0.000151607 \\
\hline & Contig3542 & tropomyosin 1 alpha chain & 0 & 0.000181928 \\
\hline & Contig3622 & PREDICTED: similar to titin immunoglobulin domain protein & 0 & 0.00021225 \\
\hline & Contig3801 & telethonin & 0 & 0.000242571 \\
\hline & Contig3825 & creatine kinase, mitochondrial 2 (sarcomeric) & 0 & 0.000272893 \\
\hline & Contig3886 & actin alpha 1 [synthetic construct] & 0 & 0.000303214 \\
\hline \multirow{10}{*}{ Liver } & Contig1600 & phenylalanine hydroxylase & 0 & 3.03214E-05 \\
\hline & Contig1797 & inter-alpha globulin inhibitor $\mathrm{H} 2$ polypeptide & 0 & $6.06428 \mathrm{E}-05$ \\
\hline & Contig1831 & FGB protein & 0 & $9.09642 \mathrm{E}-05$ \\
\hline & Contig1839 & transferrin & 0 & 0.000121286 \\
\hline & Contig1998 & Fibrinogen alpha chain & 0 & 0.000151607 \\
\hline & Contig2006 & kininogen II precursor & 0 & 0.000181928 \\
\hline & Contig2211 & retinol binding protein 4 , plasma & 0 & 0.00021225 \\
\hline & Contig2213 & hypothetical protein LOC511240 & 0 & 0.000242571 \\
\hline & Contig2363 & argininosuccinate synthetase 1 & 0 & 0.000272893 \\
\hline & Contig2557 & MGC127229 protein & 0 & 0.000303214 \\
\hline
\end{tabular}

\section{IV . ABSTRACT}

We generated 57,598 expressed sequence tags (ESTs) from 3 cDNA libraries of Hanwooo (Korean Cattle), fat, loin, liver. Liver, intermuscular fat and longissimus dorsi tissues were obtained from a 24-month-old Hanwoo steer immediately after slaughter. cDNA library was constructed according to the oligocapped method. The EST data were clustered and assembled into unique sequences, 4,759 contigs and 7,587 singletons. To carry out functional analysis, Gene Ontology annotation and identification of significant leaf nodes were performed that were detected by searching significant $p$-values from $2^{\text {nd }}$ level GO terms to leaf nodes using Bonferroni correction. We found that 13,26 and 8 significant leaf nodes are unique in the transcripts according to $3 \mathrm{GO}$ categories, molecular function, biological process and cellular component. Also digital gene expression profiling using the Audic's test was performed and tissue specific genes were detected in the above 3 libraries.

\section{REFERENCES}

1. Altschul, S. F., Madden, T. L., Schaffer, A. A., Zhang, J., Zhang, Z., Miller, W. and Lipman, D. J. 1997. Gapped BLAST and PSI-BLAST: a new generation of protein database search programs. Nucleic acids research 25(17):3389-3402.

2. Audic, S. and Claverie, J. M. 1997. The significance of digital gene expression profiles. Genome Res 7(10):986995.

3. Baumann, R. G., Baldwin, R. L., t. Van Tassell, C. P., 
Sonstegard, T. S. and Matukumalli, L. K. 2005. Characterization of a normalized cDNA library from bovine intestinal muscle and epithelial tissues. Anim Biotechnol 16(1):17-29.

4. Bonferroni, C. 1936. Teoria statistica delle classi e calcolo delle probabilit? Pubblicazioni del R Istituto Superiore di Scienze Economiche e Commerciali di Firenze 8:3-62.

5. Coulson, R. A. and Herbert, J. D. 1984. A role for carbonic anhydrase in intermediary metabolism. Ann N Y Acad Sci. 429:505-515.

6. Dvorak, C. M., Hyland, K. A., Machado, J. G., Zhang, Y., Fahrenkrug, S. C. and Murtaugh, M. P. 2005. Gene discovery and expression profiling in porcine Peyer's patch. Veterinary immunology and immunopathology 105 (3-4):301-315.

7. Ewing, B. and Green, P. 1998. Base-calling of automated sequencer traces using phred. II. Error probabilities. Genome research 8(3):186-194.

8. Gordon, D., Abajian, C. and Green, P. 1998. Consed: a graphical tool for sequence finishing. Genome research 8(3):195-202.

9. Hansen, C., Fu, A., Meng, Y., Okine, E., Hawken, R., Barris, W., Li, C. and Moore, S. S. 2004. Gene expression profiling of the bovine gastrointestinal tract. Genome 47(4):639-649.

10. Hanson, R. W. and Ballard, F. J. 1967. The relative significance of acetate and glucose as precursors for lipid synthesis in liver and adipose tissue from ruminants. Biochem J 105(2):529-536.

11. Huang, X. and Madan, A. 1999. CAP3: A DNA sequence assembly program. Genome research 9(9):868-877.

12. Lee, S. H., Park, E. W., Cho, Y. M., Kim, S. K., Lee, J. H., Jeon, J. T., Lee, C. S., Im, S. K., Oh, S. J., Thompson, J. M. and Yoon, D. 2007. Identification of differentially expressed genes related to intramuscular fat development in the early and late fattening stages of hanwoo steers. J Biochem Mol Biol 40(5):757-764.

13. Lee, S. H., Park, E. W., Cho, Y. M., Lee, J. W., Kim, H. Y., Lee, J. H., Oh, S. J., Cheong, I. C. and Yoon, D. H. 2006. Confirming single nucleotide polymorphisms from expressed sequence tag datasets derived from three cattle cDNA libraries. J Biochem Mol Biol 39(2):183-188.

14. Nafikov, R. A. and Beitz, D. C. 2007. Carbohydrate and lipid metabolism in farm animals. The Journal of nutrition 137(3):702-705.

15. Noh, S. J., Lee, K., Paik, H. and Hur, C. G. 2006. TISA: tissue-specific alternative splicing in human and mouse genes. DNA Res 13(5):229-243.

16. Sifre, L., Berge, P., Engel, E., Martin, J. F., Bonny, J. M., Listrat, A., Taylor, R. and Culioli, J. 2005. Influence of the spatial organization of the perimysium on beef tenderness. J Agric Food Chem 53(21):8390-8399.

17. Sonstegard, T. S. and van Tassell, C. P. 2004. Bovine genomics update: making a cow jump over the moon. Genet Res 84(1):3-9.

18. Vaananen, H. K., Takala, T. E., Tolonen, U., Vuori, J. and Myllyla, V. V. 1988. Muscle specific carbonic anhydrase III is a more sensitive marker of muscle damage than creatine kinase in neuromuscular disorders. Arch Neurol 45(11):1254-1256.

19. Zadissa, A., McEwan, J. C. and Brown, C. M. 2007. Inference of transcriptional regulation using gene expression data from the bovine and human genomes. BMC Genomics 8:265.

20. Zhong, S., Storch, K. F., Lipan, O., Kao, M. C., Weitz, C. J. and Wong, W. H. 2004. GoSurfer: a graphical interactive tool for comparative analysis of large gene sets in Gene Ontology space. Applied bioinformatics 3(4):261264.

(접수일자 : 2008. 7. 11. / 수정일자 : 2009. 2. 6./

채택일자 : 2009. 2. 10.) 